\title{
ANALISIS PENGARUH INFORMASI GADAI, KUALITAS JASA DAN KUALITAS PELAYANAN TERHADAP KEPUASAN PELANGGAN PEGADAIAN SYARIAH CABANG KUALA SIMPANG KABUPATEN ACEH TAMIANG
}

\author{
Nurlatifah \\ Mahasiswa Pasca Sarjana Prodi Ekni UIN Sumatera Utara, Medan \\ e-mail : nurlatifahatam@gmail.com
}

\begin{abstract}
This research was aimed to find out empirical evidences of pawn information and service quality and care quality effecting on customer's satisfaction in Syariah pawnshops branch Kuala Simpang Aceh Tamiang Regency. Analysis tool was used is multiple linear regression. The populations in this research are customers of Syariah pawnshop branch Kuala Simpang Aceh Tamiang Regency with 100 customers as sample. Data conducted by using questionnaire technique. The results showed partially that pawn information and service quality and care quality have real effect towards customer's satisfaction. Pawn information has regression coefficient about 0.054 , service quality has regression coefficient about 0.259 , care quality has regression coefficient about 0.176 , which gives the meaning that pawn information and service quality and care quality improved will increase in the value of customer satisfaction. The research also shows that simultaneously pawn information and service quality and care quality are significantly effecting and explaining customer satisfaction at Syariah pawnshops branch Kuala Simpang Aceh Tamiang Regency about 41.3\%. Among all variables which are examined, service quality is the most dominant variable.
\end{abstract}

Keywords : pawn information, service quality, care quality, customer's satisfaction

\begin{abstract}
Abstrak
Penelitian ini bertujuan untuk mendapatkan bukti empiris pengaruh informasi gadai, kualitas jasa dan kualitas pelayanan terhadap kepuasan pelanggan pegadaian syariah cabang Kuala Simpang Kabupaten Aceh Tamiang. Alat analisis yang digunakan adalah regresi linear berganda. Populasi dalam penelitian ini adalah pelanggan/nasabah di Pegadaian Syariah Cabang Kuala Simpang Kabupaten Aceh Tamiang dengan jumlah sampel sebanyak 100 orang. Teknik pengumpulan data dilakukan dengan teknik memberikan kuesioner (angket). Hasil penelitian menunjukkan bahwa secara parsial (individual) informasi gadai, kualitas jasa dan kualitas pelayanan memiliki pengaruh nyata terhadap kepuasan pelanggan/nasabah. Informasi gadai memiliki tanda koefisien regresi sebesar 0,054, kualitas jasa memiliki tanda koefisien regresi sebesar 0,259, kualitas pelayanan memiliki tanda koefisien regresi sebesar 0,176, yang memberi arti apa-
\end{abstract}


bila informasi gadai, kualitas jasa, kualitas pelayanan ditingkatkan, maka akan terjadi peningkatan kepuasan pelanggan sebesar nilai tersebut. Penelitian juga menunjukkan bahwa informasi gadai, kualitas jasa dan kualitas pelayanan secara bersama-sama berpengaruh signifikan serta mampu menjelaskan kepuasan pelanggan Pegadaian Syariah Cabang Kuala Simpang Kabupaten Aceh Tamiang sebesar $41,3 \%$. Diantara variabel bebas yang diteliti kualitas jasa merupakan variabel yang paling dominan.

Kata Kunci : Informasi Gadai, Kualitas Jasa, Kualitas Pelayanan, Kepuasan Pelanggan

\section{PENDAHULUAN}

Berdirinya lembaga keuangan syariah baik perbankan maupun non perbankan yang terus mengalami perkembangan pesat memberi efek yang sangat baik dalam tatanan sistem keuangan di Indonesia. Lembaga keuangan syariah telah menjadi bagian dari kegiatan kehidupan perekonomian masyarakat. Lembaga keuangan syariah berperan dalam usaha-usaha pembangunan ekonomi, guna meningkatkan taraf hidup masyarakat Indonesia, salah satunya adalah Pegadaian Syariah.

Lembaga pegadaian syariah lahir disebabkan mayoritas penduduk Indonesia beragama Islam, hal inilah menyebabkan lembaga ini dianggap mampu memenuhi kebutuhan dalam bidang ekonomi serta dapat menjalankan ketentuan agama. Saat ini Pegadaian Syariah diatur dalam Peraturan Pemerintah Nomor 51 Tahun 2011 tentang Perubahan Bentuk Badan Hukum Perum Pegadaian Menjadi Perusahaan Perseroan setelah sebelumnya terdapat dua Peraturan Pemerintah yang mengatur Pegadaian Syariah yaitu PP No. 10 Tahun 1990 tentang Perubahan Bentuk Perjan Pegadaian Menjadi Perum dan PP No. 103 Tahun 2000 tentang Perum Pegadaian. Pegadaian Syariah merupakan pegadaian yang dalam menjalankan operasionalnya berpegang kepada prinsip syariah. Keberadaan Pegadaian Syariah tidak terlepas dari tujuan memberikan kesejahteraan bagi masyarakat, yaitu berupa kemudahan dalam penyaluran pembiayaan dan meminimalisasi terjadinya ketidakadilan melalui praktik riba (usury) dan ketidakpastian (gharar). Dengan adanya lembaga tersebut diharapkan dapat menjadi jalan keluar bagi masyarakat yang sedang membutuhkan uang agar tidak jatuh ke tangan para pelepas uang atau tukang ijon atau tukang rentenir yang bunganya relatif tinggi. Masyarakat mengajukan pinjaman ke perum pegadaian bukan saja karena prosedurnya yang mudah dan cepat, tetapi karena biaya yang dibebankan lebih ringan jika dibandingkan dengan para pelepas uang atau tukang ijon.

PegadaianSyariahberperansebagailembagakeuanganalternatifbagimasyarakatuntuk menetapkan pilihan dalam pembiayaan. Biasanya masyarakat yang berhubungan denganpegadaianadalahmasyarakatmenengahkebawahyangmembutuhkanpembiayaan 
Nurlatifah: Pengaruh Informasi Gadai

jangka pendek dengan margin yang rendah. Oleh karena itu, barangjaminan pegadaian dari masyarakat ini memiliki karakteristik barang sehari-hari yang mempunyai nilai. Selain itu, Pegadaian Syariah juga memfasilitasi kepemilikan emas batangan melalui penjualan secara tunai atau dengan pola angsuran dengan proses cepat dalam jangka waktu tertentu yang fleksibel. Jenis emas batangan yang disediakan oleh Pegadaian Syariah berupa logam mulia dengan kadar 99,99 \% dengan berat 5 gram, 10 gram, 25 gram, 50 gram, 100 gram, 250 gram dan 1 kilogram.

Pegadaian yang telah beroperasi secara syariah yaitu Lembaga Pegadaian Syariah Cabang Kuala Simpang, pegadaian ini membawahi tiga unit pegadaian syariah yang terletak di daerah Karang Baru, Kejuruan Muda dan Manyak Payed. Keberadaan pegadaian syariah di Kuala Simpang terus berkembang dan diminati oleh masyarakat Kuala Simpang, ini dibuktikan dengan bertambahnya kantor unit pelayanan pegadaian syariah.

Pelanggan yang menggunakan jasa pegadaian yang terus meningkat juga dapat di buktikan dengan terhimpunnya dana sebesar Rp. 2.402.763.216,- dengan jumlah rekening pengguna berjumlah 7.309 pelanggan/ nasabah serta nilai taksiran mencapai Rp. 32.594.296.673,- hingga akhir tahun 2016. Peningkatan jumlah taksiran tersebut menjadi salah satu indikasi yang menunjukkan bahwa minat masyarakat untuk menjadi pelanggan pegadaian syariah semakin meningkat. Masyarakat sebagai pelanggan percaya untuk menggunakan jasa pegadaian syariah. Dari rasa percaya tersebut akan timbul satu bentuk kepuasan pelanggan terhadap pegadaian syariah.

Salah satu tantangan dari perkembangan pegadaian adalah bagaimana meningkatkan pelayanan dalam penyajian dan penyampaian informasi kepada nasabah untuk mempertahankan nasabah. Pegadaian syariah merupakan perusahaan yang bergerak dibidang jasa, sehingga kinerja perusahaan juga menggunakan aspek non financial dalam proses pengukurannya, seperti kemampuan karyawan memberikan informasi yang berkualitas yang bisa meningkatkan kepuasan pelanggan/nasabah.

Sebagai seorang hamba yang taat, manusia harus mentaati segala perintah Tuhannya. Begitu pula bagi seorang muslim, peraturan yang telah ditetapkan dalam Islam harus ditaati serta dijalankan dengan penuh rasa tanggung jawab. Sehingga keagamaan sangat berpengaruh terhadap kehidupan sehari-hari manusia. Seseorang yang memiliki tingkat keagamaan yang tinggi, ia akan terbiasa dengan segala aturan dan kewajiban yang harus ia lakukan sesuai dengan ajaran dalam Islam, sehingga tanpa disadari hidupnya akan berjalan secara teratur. Keterbiasaan tersebut tentu akan mempengaruhi sikap dan kebiasaannya dalam kehidupan sehari-hari. Bagi umat Islam 
agama dijadikan sebagai referensi bagi pemeluknya dalam mengarahkan sikap dalam menentukan pilihan hidup untuk menjadi manusia ideal dimata Allah.

Manusia ideal atau insan kamil, jika ditinjau dari sisi psikologi, sebenarnya merupakan proses aktualisasi diri, dimana manusia mencoba dan berusaha mewujudkan akhlak Ilahi sebagai prototipenya, sehingga timbul kesadaran yang kuat untuk mengubah situasi hidupnya ke arah hidup yang bermakna.

Saat ini, iklim kompetisi dalam dunia perdagangan semakin terasa. Di sisi lain perubahan lingkungan yang demikian pesat semakin mendukung kompetisi yang sedang terjadi saat ini. Pegadaian sebagai perusahaan yang bergerak dibidang jasa tentunya harus memberikan perhatian yang lebih besar terhadap pelaksanaan bauran pemasaran jasa (marketing mix), karena masing-masing dari variabel bauran pemasaran jasa (produk, harga, promosi, tempat,orang, bukti fisik, dan proses) sangat berpengaruh terhadap tingkat penggunaan jasa Pegadaian. Produk-produk yang ditawarkan, promosi yang dilakukan, harga atau bagi hasil yang ditetapkan, jauh dekatnya lokasi dari pelanggan, kenyamanan lingkungan fisik dan cepat atau lambatnya memperlihatkan kualitas pelayanan yang diberikan.

Kepuasan pelanggan merupakan suatu tingkatan dimana kebutuhan, keinginan, dan harapan dari pelanggan dapat terpenuhi yang mengakibatkan terjadinya pembelian ulang atau kesetiaan yang berlanjut. Faktor yang penting untuk menciptakan kepuasan konsumen adalah kinerja dan kualitas dari layanan yang di berikan oleh organisasi. Jika pelayanan yang diberikan memenuhi permintaan pelanggan, maka pelanggan akan merasa puas dan bila jasa pelayanan berada di bawah tingkat yang diharapkan, pelanggan akan merasa kurang / tidak puas. Pelanggan yang merasa tidak puas terhadap kualitas pelayanan yang diberikan, dengan sendirinya akan menceritakan kepada orang lain sebagai komplain atas ketidakpuasannya. Oleh karena itu pengukuran kepuasan akan pelayanan yang diberikan oleh perusahaan pada masyarakat harus selalu dilakukan untuk mengetahui dan merencanakan strategi yang lebih baik di masa mendatang dan lebih meningkatkan kualitas pelayanannya agar dapat memenuhi keinginan dan kebutuhan konsumen serta untuk meminimalisasikan masalah.

Kualitas jasa juga mempunyai peranan yang penting untuk membentuk kepuasan pelanggan. Semakin berkualitas produk dan jasa yang diberikan, maka kepuasan yang dirasakan oleh pelanggan semakin tinggi. Bila kepuasan pelanggan semakin tinggi, maka dapat menimbulkan keuntungan bagi badan usaha atau organisasi pemberi layanan tersebut. Suatu perusahaan yang bergerak dibidang apapun dikatakan berhasil apabila perusahaan tersebut dapat memberikan sesuatu kegiatan pembelian atau penggunaan jasa yang sesuai dengan keinginan kebutuhan pelanggan sehing- 
Nurlatifah: Pengaruh Informasi Gadai

ga mereka merasa puas dengan pelayanan dari perusahaan tersebut, sehingga akan mengakibatkan peningkatan terhadap pendapatan.

Sebuah riset tahun 2004 yang dilakukan oleh J.D. Power, perusahaan spesialis pengukur kepuasan pelanggan dalam industri otomotif, membuktikan bahwa perusahaan yang berhasil meningkatkan kepuasan pelanggan dalam jangka waktu lima tahun (1999-2004) mengalami kenaikan nilai bagi pemegang sahamnya sebesar $+52 \%$. Sebaliknya, perusahaan yang mengalami penurunan nilai kepuasan pelanggan, pemegang sahamnya juga mengalami penurunan nilai sebesar -28\%. Riset Claes Fornell juga membuktikan, di masa krisis 2008, saham perusahaan dengan Indeks Kepuasan Pelanggan Amerika (American Customer Satisfaction Index/ACSI) yang baik, hanya menurun $-33 \%$, sedangkan perusahaan dengan indeks yang buruk menurun $-55 \%$. Jadi, kepuasan konsumen bukan saja berharga di masa ekonomi baik, tetapi juga di saat ekonomi buruk.

Dalam bisnis, pelayanan harus dipandang sebagai satu kesatuan dari produk yang ditawarkan. Tanpa pemahaman seperti itu, sangat sulit suatu perusahaan untuk dapat memasuki persaingan yang semakin kompetitif. Sebagai suatu kemutlakan bagi setiap perusahaan dalam memasuki kancah persaingan yang semakin kompetitif, konsumen harus dipuaskan, di mana kepuasan konsumen akan tercipta manakala keinginan dan harapannya dapat diwujudkan oleh perusahaan. Kualitas pelayanan yang maksimal, merupakan strategi yang tepat dalam mewujudkan setiap keinginan dan harapan.

Kualitas layanan mendorong pelanggan untuk komitmen kepada produk dan layanan suatu perusahaan sehingga berdampak kepada peningkatan market share suatu produk. Kualitas layanan sangat krusial dalam mempertahankan pelanggan dalam waktu yang lama. Perusahaan yang memiliki layanan yang superior akan dapat memaksimalkan performa keuangan perusahaan.

Semakin tingginya tingkat persaingan, akan menyebabkan pelanggan menghadapi lebih banyak alternatif produk, harga dan kualitas yang bervariasi, sehingga pelanggan akan selalu mencari nilai yang dianggap paling tinggi dari beberapa produk. Kualitas yang rendah akan menimbulkan ketidakpuasan pada pelanggan, tidak hanya pelangganyangmenggunakanjasapegadaiansyariahtetapijugaberdampakpadaperusahaanlain.Karenapelangganyangkecewaakanberceritapalingsedikitkepada15orang lainnya. Dampaknya, calon pelanggan akan menjatuhkan pilihannya kepada pesaing. Upaya perbaikan sistem kualitas pelayanan, akan jauh lebih efektif bagi keberlangsungan bisnis. 
Kepuasan dan ketidakpuasan pelanggan akan suatu layanan akan memberikan dampak tersendiri kepada perilaku pembelian selanjutnya. Pelanggan pegadaian syariah yang menikmati layanan kemungkinan besar akan mendukung pegadaian syariah, melalui berkata positif tentang pegadaian syariah, merekomendasikan pegadaian syariah ke pihak lain, jarang melakukan perpindahan. Kesediaan pelanggan kepada pegadaian adalah suatu indikasi bahwa layanan yang diberikan bersifat favorable (disukai), disamping itu pelanggan cenderung kembali untuk mengurangi risiko kesalahan.

Seiring bergulirnya perdagangan bebas di masyarakat dalam era globalisasi ini, masalah kualitas merupakan salah satu bagian penting dan sangat perlu mendapat perhatian yang serius bagi setiap perusahaan untuk tetap bisa bertahan dalam lingkungan bisnis. Dalam lingkungan bisnis global, konsumen telah mengalami perubahan pesat, baik dalam tuntutan mereka maupun cara-cara memenuhi tuntutan mereka. Untuk tetap survive dan berkembang dalam lingkungan bisnis yang terus berubah, manajemen perlu merubah paradigma mereka agar sikap dan tindakan mereka dalam menjalankan bisnis menjadi efektif. Perusahaan harus tahu hal-hal apa saja yang dianggap penting oleh para konsumen dan perusahaan harus berusaha untuk menghasilkan kinerja sebaik mungkin. Terciptanya kualitas layanan tentunya akan menciptakan kepuasan terhadap pengguna layanan, yang pada akhirnya dapat memberikan beberapa manfaat, diantaranya terjalin hubungan yang harmonis antara penyedia barang dan jasa dengan pelanggan, memberikan dasar yang baik bagi terciptanya kedekatan pelanggan dan membentuk suatu rekomendasi dari mulut ke mulut (word-of-mounth) yang menguntungkan bagi penyedia jasa tersebut. Implementasi kualitas jasa yang dilakukan oleh suatu perusahaan yang bergerak dibidang jasa adalah dengan cara memberikan kualitas pelayanan (service) yang terbaik bagi konsumen dengan tujuan untuk menciptakan kepuasan konsumen. Kualitas yang diberikan oleh perusahaan akan menimbulkan persepsi konsumen terhadap kualitas yang diberikan kepadanya. Seringkali terdapat perbedaan antara harapan konsumen dengan persepsi konsumen terhadap kualitas yang diberikan perusahaan. Untuk mengetahui apakah perusahaan telah memberikan kualitas jasa yang sesuai dengan harapan konsumen, maka perlu dilakukan evaluasi dari konsumennya.

Pada kondisi perekonomian yang demikian maka perusahaan dituntut untuk memanfaatkan kemampuan yang ada semaksimal mungkin agar unggul dalam persaingan, oleh karena itu perusahaan harus memiliki manajemen yang baik dan tangguh sehingga dapat mengidentifikasi masalah dan menyeleksi serta mengimplementasikannya dengan tepat. Untuk dapat meningkatkan kinerjanya maka manajer harus dapat menjalankan fungsi manajemen dengan baik yaitu perencanaan, pengorganisasian, pelaksanaan, dan pengendalian. Karena pelayanan atau service merupakan faktor 
Nurlatifah: Pengaruh Informasi Gadai

penentu bagi seseorang yang menyangkut kepuasan pelanggan, apabila pelanggan merasa amat puas maka mereka amat sukar untuk mengubah pikirannya dan hasilnya adalah kesetiaan pelanggan yang tinggi, sebaliknya jika pelanggan tidak puas tentunya mereka akan mudah berubah pikiran apabila mendapat penawaran yang lebih baik.

Saat ini, pelanggan lebih sulit terpuaskan karena pelanggan lebih cerdas, lebih sadar harga, lebih menuntut, kurang memaafkan dan didekati oleh banyak pesaing dengan tawaran yang sama atau lebih baik. Tantangannya menurut Kotler adalah bukan hanya menghasilkan pelanggan yang puas, beberapa pesaing dapat melakukan itu. Tantangannya adalah menghasilkan pelanggan yang senang dan setia.

Dengan demikian, kunci agar perusahan tetap eksis adalah kemampuan perusahaan untuk mempertahankan pelanggannya. Apabila pelanggan pergi (defeksi), maka eksistensi perusahaan tidak diperlukan lagi. Oleh karena itu, perusahaan perlu mendeteksi sikap pelanggannya. Pemahaman pemasar terhadap sikap pelanggan, dapat membantu pemasar untuk dapat mempengaruhi dan mengubah sikap konsumen ke arah yang positif.

Dari penjelasan di atas, dapat dilihat bahwa sangatlah penting bagi setiap lembaga yang ingin memenangkan persaingan harus memberikan perhatian penuh dan pelayanan terbaik kepada para pelanggan sehingga harus meningkatkan fasilitas dan kualitas pelayanan kepada pelanggan agar terjaga hubungan yang baik antara kedua belah pihak serta terciptanya kepuasan. Berdasarkan latar belakang yang telah diuraiakan di atas, maka penulis merasa tertarik untuk meneliti "ANALISIS PENGARUH INFORMASI GADAI, KUALITAS JASA DAN KUALITAS PELAYANAN TERHADAP KEPUASAN PELANGGAN PEGADAIAN SYARIAH CABANG KUALA SIMPANG KABUPATEN ACEH TAMIANG"

\section{METODE PENELITIAN}

Penelitian ini merupakan penelitian survey yang bertujuan untuk mengetahui variabel apa saja yang mempengaruhi kepuasan pelanggan/nasabah pegadaian syariah. Menurut Kelinger, Survey adalah penelitian yang dilakukan pada pupulasi besar maupun kecil, tetapi data yang dipelajari adalah data dari sampel yang diambil dari populasi tersebut. Sehingga ditemukan kejadian-kejadian relative, distribusi dan hubungan-hubungan antar variabel sosiologis maupun psikologis.

Penelitian ini menggunakan metode Kuantitatif sebagai pendekatan untuk menjawab permasalahan, disebabkan karena data yang pe- 
neliti ambil dalam bentuk angka dan akan diproses secara statistik. Penelitian ini akan menguji pengaruh variabel bebas terhadap variabel terikat, dengan menggunakan regresi linier berganda, selain juga akan diuji pengaruh masing-masing variabel independen terhadap variabel terikat, baik secara parsial maupun secara simultan (bersama-sama). Variabel bebas terdiri atas informasi gadai, kualitas dari jasa yang ditawarkan dan kualitas pelayanan. Sedangkan variabel terikat berupa kepuasan pelanggan/nasabah. Pelanggan/ nasabah yang dimaksud adalah pelanggan/ nasabah pegadaian syariah Kuala Simpang.

Pada penelitian ini, yang menjadi target populasi adalah seluruh masyarakat yang tergolong sebagai pengguna jasa gadai di Pegadaian Syariah Cabang Kuala Simpang, Sehingga saat ini jumlah populasi di pegadaian Syariah yang terlibat aktif dalam transaksi gadai di pegadaian syariah cabang Kuala Simpang sebesar 5.338 orang. Hal ini menunjukkan bahwa gadai merupakan suatu transaksi yang banyak digunakan sebagai aktifitas masyarakat di Kuala Simpang. Teknik pengambilan sampel dalam penelitian ini yaitu secara aksidental. Menurut Sugiyono, metode Aksidental adalah teknik penentuan sampel berdasarkan kebetulan bertemu dengan peneliti dapat digunakan sebagai sampel, bila dipandang orang yang kebetulan ditemui itu cocok sebagai sumber data. Penarikan sampel secara aksidental didasarkan pada kemudahan (Convenience). Sampel dapat dipilih karena berada pada waktu, situasi, dan tempat yang tepat. Mengingat segala keterbatasan yang dimiliki peneliti, maka peneliti menggunakan sampel sebagai sumber data dalam penelitian ini dengan rumus Slovin.

$$
\begin{aligned}
& \mathrm{n}=\mathrm{N} \\
& \frac{1+\mathrm{N}(\mathrm{e})^{2}}{\text { Keterangan: }}
\end{aligned}
$$$$
\mathrm{n}=\text { Besaran Sampel }
$$$$
\mathrm{N}=\text { Besaran populasi }
$$

e = Nilai Kritis (batas penelitian) yang diinginkan (persen kelonggaran ketidak telitian karena kesalahan penarikan sampel)

Pada penelitian ini nilai kritis yang diambil sebesar $10 \%$ dengan jumlah populasi sebesar 5.338 orang oleh karena itu, sampel yang digunakan dalam penelitian ini berjumlah 100 orang pelanggan/ nasabah Pegadaian Syariah yang melakukan transaksi.

Dalam model analisis ini, terdapat dependent variable serta independent variable. Dependent variable merupakan variabel yang dapat diukur, diprediksi, atau dengan kata lain dapat dimonitor dan diharapkan dipengaruhi oleh variabel bebas (informasi gadai, kualitas jasa dan kualitas pelayanan) serta Independent variable adalah variabel yang mempengaruhi variabel terikat (kepuasan pelanggan). 


\section{Paradigma Penelitian}

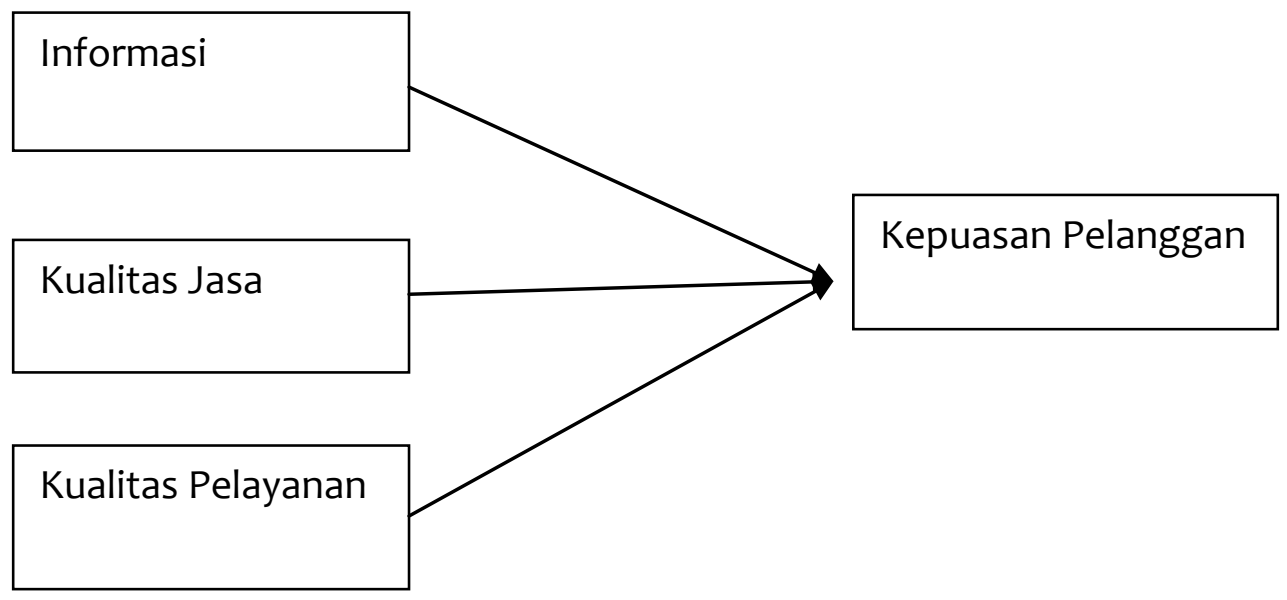

Jenis data yang digunakan dalam kasus ini adalah kuantitatif. Berbasis pada penelitian lapangan (field research), data yang digunakan dalam penelitian ini adalah data primer, yaitu penulis mengumpulkan data dengan cara membagikan kuesioner kepada pelanggan/ nasabah Pegadaiaan Syariah yang menggunakan jasa gadai Syariah di Pegadaian Kuala Simpang Kabupaten Aceh Tamiang. Teknik pengumpulan data menggunakan metode survey, yaitu suatu cara penyelidikan yang diadakan untuk memperoleh fakta atau gejala yang ada dan mencari keterangan-keterangan secara faktual. Pengumpulan data dilakukan melalui metode kuesioner (angket) adalah teknik pengumpulan data yang dilakukan dengan cara memberi seperangkat pertanyaan atau pertanyaan tertulis kepada responden untuk dijawab. ${ }^{1}$ Hasil dari kuesioner yang terkumpul, kemudian dijadikan bahan untuk dianalisa secara kuantitatif. Berdasarkan latar belakang masalah yang telah dikemukakan di atas, maka rumusan masalah dalam penelitian ini adalah :

1. Apakah informasi gadai, kualitas jasa, kualitas pelayanan berpengaruh terhadap kepuasan pelanggan?

2. Variabel manakah yang paling dominan berpengaruh terhadap kepuasan pelanggan?

\section{PEMBAHASAN}

Dalam rangka menjawab hipotesis yang telah diajukan maka akan dilakukan serangkaian pengujian dan analisis statistik. Diantara uji dan analisis tersebut adalah uji 
asumsi klasik (multikolinearitas, normalitas, heterokedastisitas, autokorelasi), uji t dan uji F.

\section{UJi Asumsi Klasik}

Uji asumsi klasik, bertujuan untuk memperoleh model regresi yang menghasilkan estimator linier tidak bias yang terbaik. Pengujian ini dimaksudkan untuk mendeteksi adanya penyimpangan asumsi klasik pada persamaan regresi berganda. Uji asumsi klasik yang digunakan dalam penelitian yaitu multikolinearitas, normalitas, heteroskedastisitas, dan autokorelasi.

\section{a. Uji Multikolinearitas}

Pengujian ini bertujuan untuk mengetahui apakah setiap variabel saling berhubungan secara linear atau tidak. Untuk melihat ada tidaknya multikolinearitas dengan melihat korelasi antar variabel bebas, apabila ada korelasi antara variabel bebas cukup tinggi atau di atas 0,90 maka mengindikasikan adanya multikolinearitas. Selain itu dapat juga dengan melihat nilai Tolerance dan Variance Inflation Factor (VIF), apabila Tolerance lebih besar dari 0,10 (10\%) atau nilai VIF lebih kecil dari 10 maka tidak terjadi multikolinearitas. Model regresi yang baik seharusnya tidak terjadi korelasi diantara variabel independen.

Tabel 28

Hasil Uii Multikolinearitas

\begin{tabular}{|c|c|c|c|}
\hline \multicolumn{4}{|c|}{ Coefficients $^{a}$} \\
\hline \multirow{2}{*}{\multicolumn{2}{|c|}{ Model }} & \multicolumn{2}{|c|}{ Collinearity Statistics } \\
\hline & & Tolerance & VIF \\
\hline \multirow[t]{4}{*}{1} & (Constant) & & \\
\hline & Informasi Gadai & ,789 & 1,267 \\
\hline & Kualitas Jasa & 420 & 2,381 \\
\hline & $\begin{array}{l}\text { Kualitas } \\
\text { Pelayanan }\end{array}$ & ,389, & 2,569 \\
\hline
\end{tabular}

a. Dependent Variable: Kepuasan Pelanggan

Sumber: data diolah penulis, 2017.

Berdasarkan tabel 28 dari hasil uji multikolinearitas (uji VIF) menunjukkan bahwa uji VIF kurang dari 10 dan tolerance lebih dari 0,1 berarti bahwa model regresi tidak mengandung multikolinearitas yaitu tidak terjadi korelasi diantara variabel independen. Jika variabel independen saling berkorelasi, maka variabel ini tidak ontogonal (variabel independen yang nilai korelasi antar sesama variabel independen sama dengan nol). 


\section{b. Uji Normalitas}

Uji Normalitas dalam penelitian ini menggunakan uji statistik dengan analisis grafik. Pengujian ini dilakukan dengan menggunakan histogram dengan menggunakan variabel dependent sebagai sumbu vertical sedangkan nilai residual terstandarisasi digambarkan sebagai sumbu horizontal. Jika Histogram Standarizel Residual membentuk kurva seperti lonceng maka nilai residual tersebut dinyatakan normal. Model kedua dalam penelitian ini dengan menganalisis Normal Probability Plot, yaitu dengan membandingkan distribusi kumulatif dari data sesungguhnya dengan distribusi kumulatif dari distribusi normal. Distribusi normal digambarkan dengan sebuah garis diagonal lurus dari kiri bawah kekanan atas. Distribusi sesungguhnya digambarkan dengan ploting. Jika data normal maka garis yang menggambarkan data sesungguhnya akan mengikuti atau merapat kegaris diagonalnya. ${ }^{2}$

Gambar 4. 1

Hasil Uji Normalitas bentuk Histogram Menggunakan IBM SPSS

Histogram

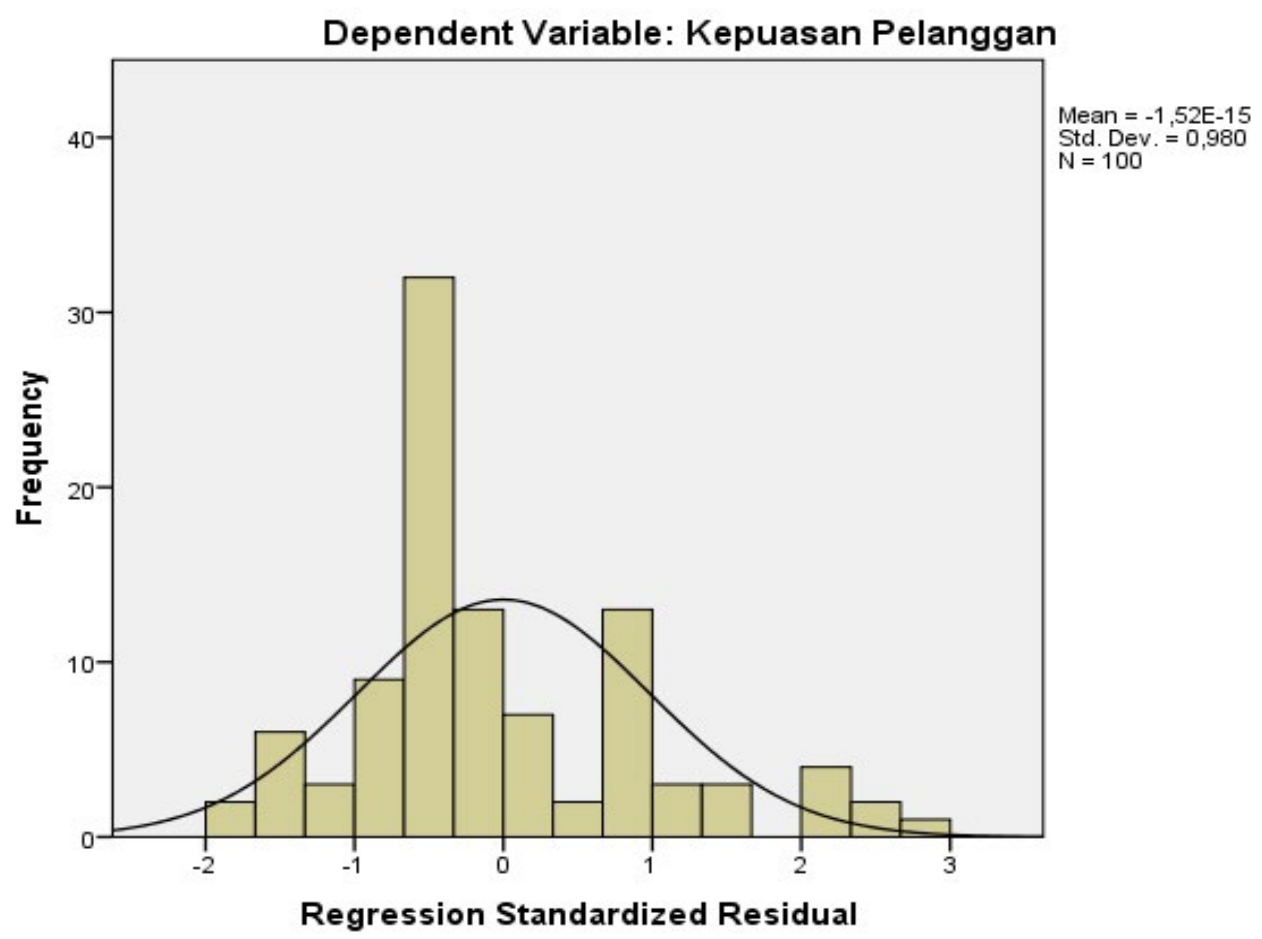

Berdasarkan gambar 4.1 tampilan histogram menunjukkan bahwa kurva dependen dan regression standardized residual membentuk gambar seperti lonceng. Oleh karena itu berdasarkan uji normalitas, analisis regresi layak digunakan. 
Gambar 4.2

Hasil Uji Normalitas bentuk Normal Probability Plot Menggunakan IBM SPSS

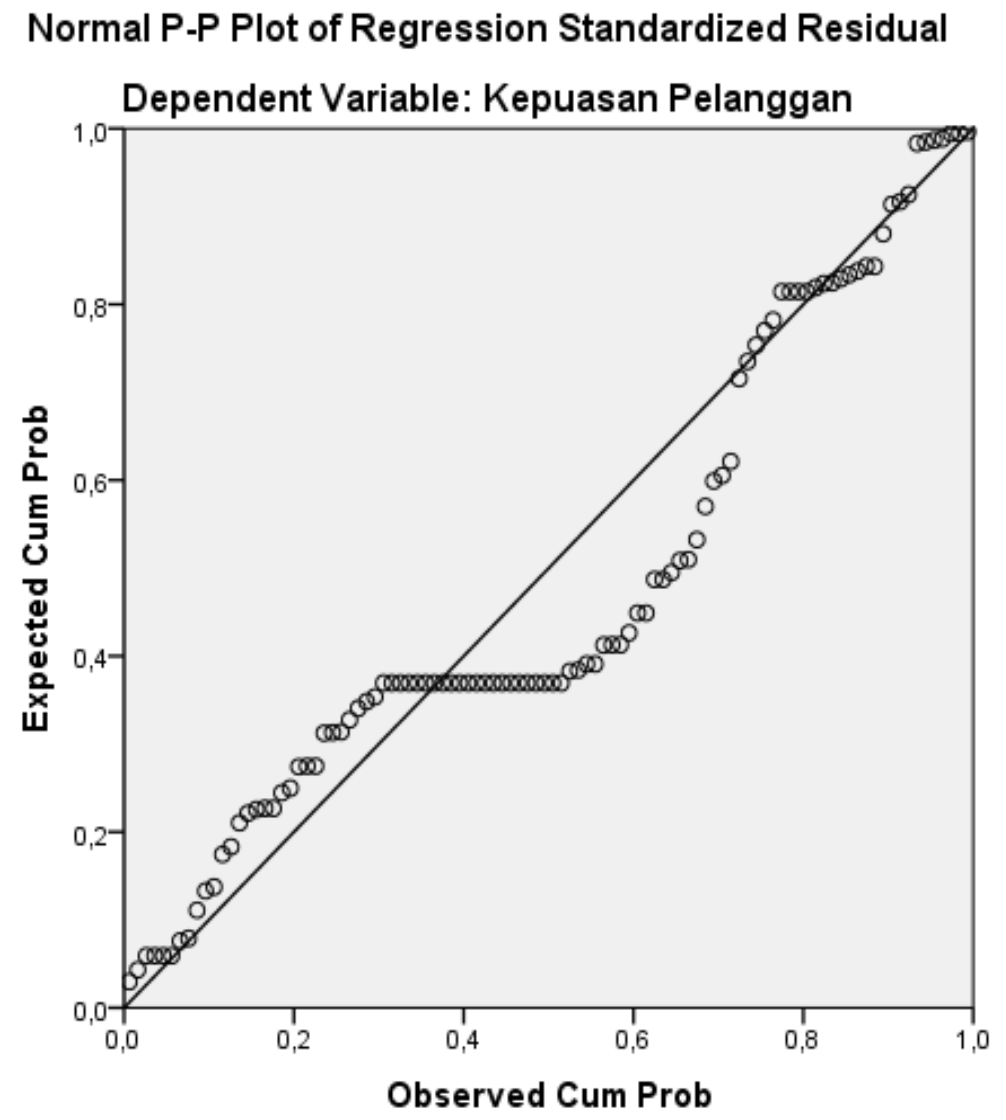

Berdasarkan gambar 4.2 tampilan Normal Probability Plot regression standardized residual terlihat bahwa titik-titik menyebar disekitar garis diagonal. Oleh karena itu berdasarkan uji normalitas, analisis regresi layak digunakan.

\section{c. Uji Heteroskedastisitas}

Heteroskedastisitas terjadi jika varians dari residual dari suatu pengamatan ke pengamatan yang lain berbeda. Model regresi yang baik adalah tidak terjadi heteroskedastisitas. Untuk menguji heteroskedastisitas dengan melihat grafik scatterplot, jika tidak ada pola yang jelas, serta titik-titik menyebar di atas dan di bawah angka o pada sumbu $\mathrm{Y}$, maka tidak terjadi heteroskedastisitas. 
Nurlatifah: Pengaruh Informasi Gadai

\section{Gambar 4.3}

Hasil Uji Heteroskedastisitas Menggunakan IBM SPSS

\section{Scatterplot}

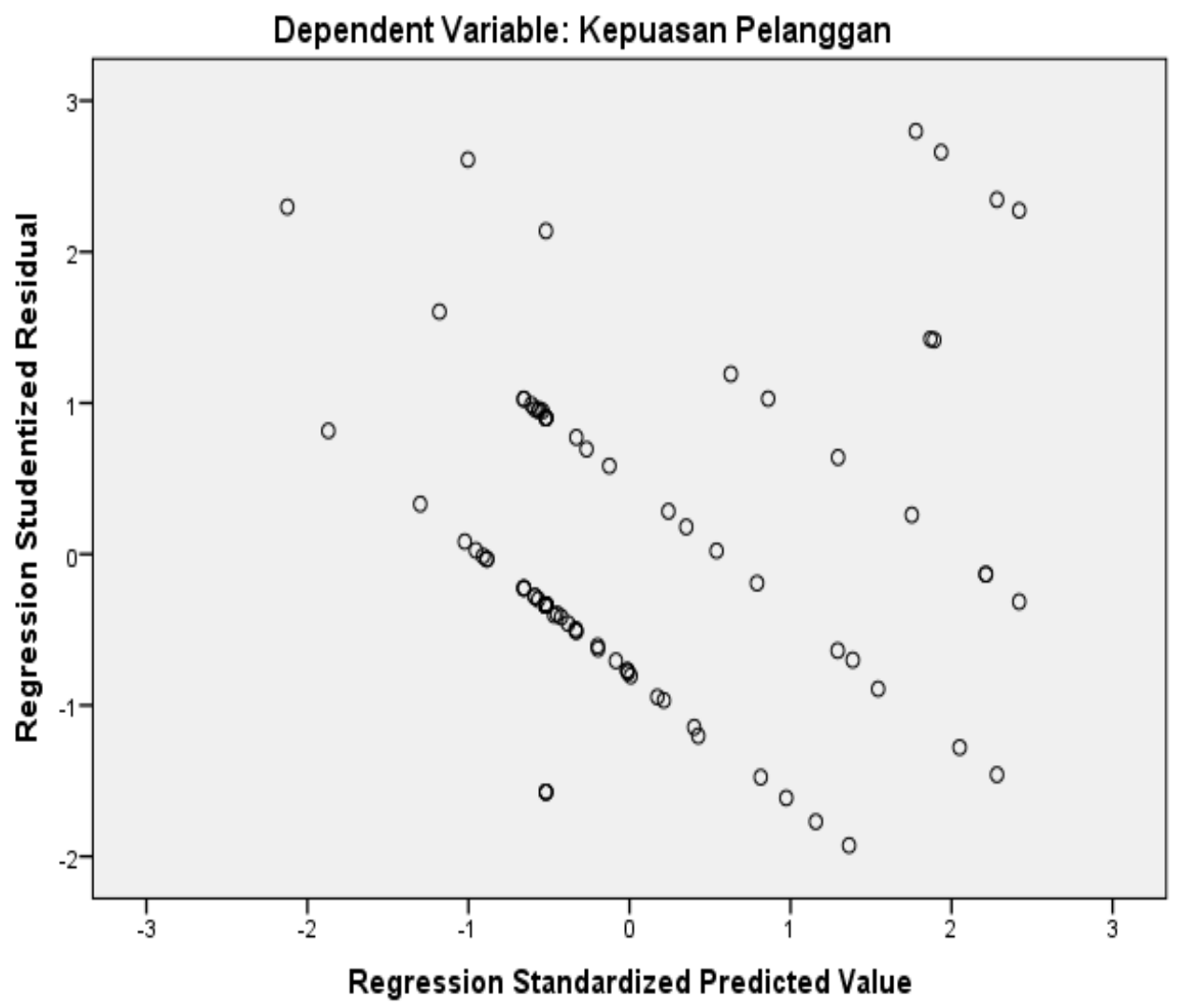

Berdasarkan gambar 4.3 terlihat bahwa titik-titik pada grafik Plot menyebar atau tidak membentuk pola tertentu. Artinya, tidak terjadi heteroskedastisitas pada model regresi yang digunakan.

\section{d. Uji Autokorelasi}

Uji autokorelasi yang digunakan dalam penelitian ini menggunakan model Summary. Uji ini dilakukan untuk melihat seberapa besar faktor pengganggu, dengan menggukan program IBM SPSS. Didapatkan hasil sebagai berikut:

\begin{tabular}{|c|c|c|c|}
\hline \multicolumn{4}{|c|}{ Variables Entered/Removed ${ }^{a}$} \\
\hline Model & Variables Entered & Variables Removed & Method \\
\hline 1 & $\begin{array}{l}\text { Kualitas Pelayanan, Informasi } \\
\text { Gadai, Kualitas Jasa }{ }^{\text {b }}\end{array}$ & . & Enter \\
\hline
\end{tabular}

a. Dependent Variable: Kepuasan Pelanggan

b. All requested variables entered. 


\begin{tabular}{|l|l|l|l|l|l|}
\hline \multicolumn{5}{|l|}{ Model Summary } \\
\hline Model & $\mathrm{R}$ & R Square & Adjusted R Square & $\begin{array}{l}\text { Std. Error of } \\
\text { the Estimate }\end{array}$ & Durbin-Watson \\
\hline 1 &, $642^{\mathrm{a}}$ &, 413 &, 394 &, 81117 & 1,855 \\
\hline
\end{tabular}

a. Predictors: (Constant), Kualitas Pelayanan, Informasi Gadai, Kualitas Jasa

b. Dependent Variable: Kepuasan Pelanggan

Pada model summary dapat dilihat jika nilai Durbin-Watson diantara du dan 4 du berarti tidak terdapat autokorelasi sedangkan output model summary diatas terlihat bahwa nilai Durbin-Watson sebesar 1,855. Maka dapat disimpulkan pada model regresi tidak mengandung permasalahan autokorelasi.

\section{e. Metode Analisis Data}

\section{a. Analisis Regresi Berganda}

Penelitian ini bertujuan untuk menguji pengaruh Informasi Gadai ( $\left.X^{1}\right)$, Kualitas Jasa $\left(X^{2}\right)$ dan Kualitas Pelayanan $\left(X^{3}\right)$ sebagai variabel bebas (independen) sedangkan kepuasan pelanggan/nasabah sebagai variabel terikat (dependen). Pengolahan data penelitian ini menggunakan aplikasi komputer IBM SPSS Statistic 23, maka diperoleh diperoleh hasil sebagai berikut:

Tabel 29

Rekapitulasi Hasil Analisa Regresi Berganda

\section{Coefficients $^{\mathrm{a}}$}

\begin{tabular}{|c|c|c|c|c|c|c|}
\hline \multirow{2}{*}{\multicolumn{2}{|c|}{$\begin{array}{l}\text { Model } \\
\text { B }\end{array}$}} & \multicolumn{2}{|c|}{$\begin{array}{l}\text { Unstandardized } \\
\text { Coefficients } \\
\end{array}$} & \multirow[t]{2}{*}{$\begin{array}{l}\text { Standardized Coef- } \\
\text { ficients }\end{array}$} & \multirow[t]{2}{*}{$\mathrm{t}$} & \multirow[t]{2}{*}{ Sig. } \\
\hline & & $\begin{array}{l}\text { Std. } \\
\text { Error }\end{array}$ & Beta & & & \\
\hline \multirow[t]{4}{*}{1} & (Constant) & 8,464 & 1,116 & & 7,585 &, 000 \\
\hline & Informasi Gadai &, 054 &, 066 &, 073 & ,824 &, 412 \\
\hline & Kualitas Jasa & ,259 &, 082 & ,383 & 3,173 &, 002 \\
\hline & $\begin{array}{l}\text { Kualitas Pe- } \\
\text { layanan }\end{array}$ &, 176 & 084 & ,263 & 2,097 & ,039 \\
\hline
\end{tabular}

Sumber: Data diolah penulis, 2017.

Berdasarkan tabel 29 dapat dibuat persamaan regresi linier berganda sebagai berikut: 
$\mathrm{Y}=\mathrm{a}+\mathrm{bX} 1+\mathrm{bX}_{2}+\mathrm{bX}_{3}+\mathrm{e}$

$Y=8,464+0,054 X^{1}+0,259 X^{2}+0,176 X^{3}+e$

$S E=1,116+0,066+0,082+0,084$

$t=(7,585)(0,824)(3,173)(2,097)$

Sig. $=0,000(0,412)(0,002)(0,039)$

Konstanta sebesar 8,464 menyatakan bahwa jika informasi Gadai (X'), Kualitas Jasa $\left(\mathrm{X}^{2}\right)$ dan Kualitas Pelayanan $\left(\mathrm{X}^{3}\right)$ bernilai tetap, maka kepuasan pelanggan ( $\mathrm{Y}$ ) Pegadaian Syariah Cabang Kuala Simpang akan bernilai tetap yaitu sebesar 8,464. Dari persamaan regresi linier berganda tersebut diperoleh koefisien masing-masing variabel sebagai berikut:

1. Koefisien regresi informasi gadai $\left(X^{1}\right)$ sebesar 0,054 , berarti setiap peningkatan informasi gadai 1 skor akan meningkatkan kepuasan pelanggan/nasabah sebesar 0,054 .

2. Koefisien regresi kualitas jasa $\left(X^{2}\right)$ sebesar 0,259 berarti setiap peningkatan kualitas jasa 1 skor akan meningkatkan kepuasan pelanggan/nasabah sebesar 0,259.

3. Koefisien kualitas pelayanan $\left(X^{3}\right)$ sebesar 0,176 berarti setiap peningkatan kualitas pelayanan 1 skor akan meningkatkan kualitas pelayanan sebesar 0,176.

4. Standar error sebesar 1,116 artinya seluruh variabel yang dihitung dalam uji IBM SPSS memiliki tingkat variabel pengganggu sebesar 1,116 .

\section{b. Koefisien Determinasi}

Koefisien determinasi digunakan untuk mengetahui kemampuan variabel independen dalam menjelaskan variabel dependen. Besarnya koefesien determinasi dapat dilihat pada $r$ square dan dinyatakan dalam presentase. Nilai koefisien determinasi adalah diantara nol dan satu. Nilai $R$ yang kecil berarti kemampuan variabel independen dalam menerangkan variabel dependen sangat terbatas. Nilai yang mendekati satu berarti variabel independen memberikan hampir semua informasi yang dibutuhkan untuk memprediksi variasi variabel dependen. Hasil koefisien determinasi dapat dilihat pada tabel berikut ini 
Tabel 30

Koefisien Determinasi

\begin{tabular}{|l|l|l|l|l|l|}
\hline \multicolumn{4}{|l|}{ Model Summary } \\
\hline Model & R & R Square & $\begin{array}{l}\text { Adjusted R } \\
\text { Square }\end{array}$ & $\begin{array}{l}\text { Std. Error of the } \\
\text { Estimate }\end{array}$ & Durbin-Watson \\
\hline 1 &, $642^{\mathrm{a}}$ &, 413 &, 394 &, 81117 & 1,855 \\
\hline
\end{tabular}

a. Predictors: (Constant), Kualitas Pelayanan, Informasi Gadai, Kualitas Jasa

b. Dependent Variable: Kepuasan Pelanggan

Tabel 30 menampilkan korelasi $(R)$ variabel bebas (informasi gadai, kualitas jasa dan kualitas pelayanan dengan variabel terikat (kepuasan pelanggan/nasabah) sebesar 0,642 dengan R-Square sebesar 0,413. Ini berarti bahwa informasi gadai, kualitas jasa dan kualitas pelayanan mampu menentukan kepuasan pelanggan/nasabah mencapai sebesar $41,3 \%(0,413 \times 100 \%)$ dan sisanya sebesar $58,7 \%$ (100\% - 41,3\%) ditentukan oleh variabel lain di luar model penelitian ini. Sedangkan nilai Standard Error of the Estimate hanya sebesar 0,81117 .

\section{c. Uji F}

Uji simultan atau uji F merupakan uji secara bersama-sama untuk menguji

signifikan pengaruh variabel yang terdiri atas informasi gadai, kualitas jasa dan kualitas pelayanan secara bersama-sama terhadap variabel kepuasan pelanggan.

Ketentuan untuk menerima atau menolak hipotesis mengunakan kriteria yaitu:

a. Jika F hitung > F tabel, maka Ho ditolak.

b. Jika F hitung < F tabel, maka Ho diterima.

Atau dapat juga berdasarkan probabilitas:

a. Jika probabilitas > 0,05, maka Ho diterima.

b. Jika probabilitas < 0,05 maka Ho ditolak dan Ha diterima.

Hasil pengujian diperoleh hasil yaitu: 
Nurlatifah: Pengaruh Informasi Gadai

Tabel 31

\begin{tabular}{|l|l|l|l|l|l|l|}
\hline \multicolumn{2}{|l|}{ ANOVA $^{\text {a }}$ Model } & $\begin{array}{l}\text { Sum of } \\
\text { Squares }\end{array}$ & df & Mean Square & F & Sig. \\
\hline \multirow{3}{*}{1} & Regression & 44,393 & 3 & 14,798 & 22,489 &, $000^{\mathrm{b}}$ \\
\cline { 2 - 8 } & Residual & 63,167 & 96 &, 658 & & \\
\cline { 2 - 8 } & Total & 107,560 & 99 & & & \\
\hline
\end{tabular}

a. Dependent Variable: Kepuasan Pelanggan

b. Predictors: (Constant), Kualitas Pelayanan, Informasi Gadai, Kualitas Jasa

Berdasarkan hasil pengujian seperti pada tabel 31 menunjukkan bahwa nilai F sebesar 22,489 dengan probabilitas sebesar 0,000. Sementara harga F-tabel untuk jumlah data pengamatan sebanyak 100 dengan taraf signifikansi $5 \%$, dengan dk pembilang atau $\mathrm{k}$ (jumlah variabel indenpenden) $=2$, serta $\mathrm{dk}$ penyebut $=100(\mathrm{n}-\mathrm{k}-1)=95$, diperoleh F-tabel sebesar 2,53. Jika harga F-hitung dibandingkan dengan harga F-tabel, maka diperoleh bahwa:

22,489>2,53: Ha diterima dan Ho ditolak

Begitu juga jika dibandingkan dengan probabilitas (Sig.), diperoleh sebagai berikut:

$0,000<0,05:$ Ha diterima dan Ho ditolak

Berdasarkan kriteria penerimaan atau penolakan hipotesis, dengan melihat hasil pengolahan data tersebut maka diperoleh keputusan bahwa informasi gadai, kualitas jasa dan kualitas pelayanan secara bersama-sama memiliki pengaruh nyata terhadap kepuasan pelanggan/nasabah pegadaian syariah cabang Kuala Simpang.

Berdasarkan pengujian statistik dengan metode uji $\mathrm{F}$, di mana tingkat signifikan yang diperoleh lebih kecil yakni sebesar 0,000 dari standar signifikan yakni $5 \%$ atau 0,05 dan perbandingan antara $\mathrm{F}$ hitung dan $\mathrm{F}$ tabel, di mana $\mathrm{F}$ hitung sebesar 22,489 lebih besar dari $\mathrm{F}$ tabel yakni 2,53 maka dapat disimpulkan bahwa Ha diterima atau informasi gadai, kualitas jasa dan kualitas pelayanan memiliki pengaruh terhadap kepuasan pelanggan.

\section{d. Ujit}

Pengujian ini untuk melihat sejauh mana pengaruh secara sendiri-sendiri variabel $X$ terhadap variabel $Y$.

Berdasarkan hasil pengolahan dengan program IBM SPSS Statistic 23 maka di dapat 
hasil uji t, yang hasilnya dirangkum pada tabel berikut ini :

Tabel 29

Hasil Uji t

\section{Coefficients $^{\mathrm{a}}$}

\begin{tabular}{|c|c|c|c|c|c|c|}
\hline \multirow{2}{*}{\multicolumn{2}{|c|}{$\begin{array}{l}\text { Model } \\
\text { B }\end{array}$}} & \multicolumn{2}{|c|}{$\begin{array}{l}\text { Unstandardized } \\
\text { Coefficients }\end{array}$} & \multirow{2}{*}{$\begin{array}{l}\text { Standard- } \\
\text { ized Coeffi- } \\
\text { cients } \\
\end{array}$} & \multirow[t]{2}{*}{$\mathrm{t}$} & \multirow[t]{2}{*}{ Sig. } \\
\hline & & \multirow{2}{*}{\begin{tabular}{|l|}
$\begin{array}{l}\text { Std. } \\
\text { Error }\end{array}$ \\
8,464 \\
\end{tabular}} & \multirow{2}{*}{\begin{tabular}{|l|} 
Beta \\
1,116 \\
\end{tabular}} & & & \\
\hline \multirow[t]{4}{*}{1} & (Constant) & & & & 7,585 &, 000 \\
\hline & Informasi Gadai &, 054 &, 066 & ,073 & ,824 &, 412 \\
\hline & Kualitas Jasa &, 259 & ,082 & ,383 & 3,173 &, 002 \\
\hline & $\begin{array}{l}\text { Kualitas Pe- } \\
\text { layanan }\end{array}$ &, 176 &, 084 & ,263 & 2,097 &, 039 \\
\hline
\end{tabular}

Sumber: Data diolah penulis, 2017.

Hasil print out komputer dengan mempergunakan program aplikasi komputer IBM SPSS Statistic 23 diperoleh hasil informasi gadai memiliki nilai statistik (t hitung) sebesar 0,824 dan probabilitas (Sig.) sebesar 0,412. Sementara harga t-tabel untuk jumlah data pengamatan sebanyak 100 orang dengan taraf signifikansi $5 \%$ dan dk $=\mathrm{n}-2=$ 98, diperoleh t tabel sebesar 1,988. Jika harga t-hitung dibandingkan dengan harga t-tabel, maka diperoleh bahwa:

X1 : 0,824 < 1,988: Ho diterima dan Ha ditolak

$\mathrm{X} 2: 3,173<1,988:$ Ho diterima dan Ha ditolak

$\mathrm{X}_{3}: 2,097<1,988:$ Ho diterima dan Ha ditolak

Begitu juga jika dibandingkan dengan probabilitas (Sig.), diperoleh sebagai berikut:

X1: 0,412 > 0,05: Ho diterima dan Ha ditolak

$\mathrm{X}_{2}: 0,002>0,05:$ Ho diterima dan Ha ditolak

X3:0,039>0,05: Ho diterima dan Ha ditolak

Ketentuan untuk menerima atau menolak hipotesis tersebut mengunakan kriteria yaitu jika t hitung > t tabel maka Ho ditolak, sedangkan jika $t$ hitung < $t$ tabel maka Ha ditolak dan Ho diterima. Sedangkan jika menggunakan probabilitas, jika probabilitas $>$ 0,05 maka Ho diterima dan Ha ditolak, sedangkan jika probabilitas < 0,05 maka Ho ditolak dan Ha diterima. Hal ini sesuai dengan hipotesis yang menyatakan bahwa:

\section{Hipotesis Informasi Gadai, Kualitas Jasa dan Kualitas Pelayanan}


Nurlatifah: Pengaruh Informasi Gadai

Ho : Tidak ada pengaruh informasi gadai, kualitas jasa dan kualitas pelayanan terhadap kepuasan pelanggan.

Ha : Ada pengaruh informasi gadai, kualitas jasa dan kualitas pelayanan terhadap kepuasan pelanggan.

Hasil regresi berganda diatas menunjukkan bahwa variabel bebas yaitu informasi gadai, kualitas jasa dan kualitas pelayanan pada pegadaian syariah memberikan pengaruh positif terhadap variabel terikat yaitu kepuasan pelanggan/nasabah Pegadaian Syariah Cabang Kuala Simpang, Di mana setiap kenaikan yang terjadi pada variabel bebas akan diikuti pula oleh kenaikan variabel terikat dengan taraf signifikansi $95 \%$, atau $a=0,05$.

Sesuai dengan teori yang dilakukan peneliti dalam penelitian ini informasi gadai, kualitas jasa dan kualitas pelayanan memberikan pengaruh terhadap kepuasan pelanggan/nasabah dibuktikan dengan uji statistik. Menurut analisis peneliti dilapangan bahwa pelanggan yang sudah pernah bertransaksi pada pegadaian syariah memilih untuk bertransaksi kembali, dari pada bertransaksi pada lembaga lain.

Hal ini terjadi karena informasi gadai, kualitas jasa dan kualitas pelayanan telah sesuai dengan yang diharapkan oleh pelanggan sehingga proses yang dilakukan ketika bertransaksi terasa lebih mudah dan nyaman.

Jadi dapat disimpulkan bahwa semakin tinggi tingkat informasi gadai, kualitas jasa dan kualitas pelayanan akan meningkatkan kepuasan pelanggan/nasabah dengan tingkat signifikan sebesar 0,000.

\section{Hipotesis Variabel manakah yang paling dominan berpengaruh terhadap kepua- san pelanggan}

Ho : Tidak ada variabel yang berpengaruh secara dominan terhadap kepuasan pelanggan.

Ha : Ada variabel yang berpengaruh secara dominan terhadap kepuasan pelanggan.

Hasil regresi berganda diatas juga menunjukkan bahwa dari ketiga variabel bebas yaitu informasi gadai, kualitas jasa dan kualitas pelayanan pada pegadaian syariah, variabel bebas yang dominan adalah variabel kualitas jasa sebesar 3,173 dibandingkan variabel yang lain. 


\section{SIMPULAN}

Hasil penelitian menunjukkan bahwa secara parsial (individual) informasi gadai, kualitas jasa dan kualitas pelayanan memiliki pengaruh positif terhadap kepuasan pelanggan. nilai positif dapat diartikan apabila informasi gadai, kualitas jasa dan kualitas pelayanan semakin baik maka kepuasan pengguna semakin meningkat. Penelitian juga menunjukkan bahwa informasi gadai, kualitas jasa dan kualitas pelayanan secara bersama-sama berpengaruh signifikan serta mampu menjelaskan kepuasan pelanggan Pegadaian Syariah Cabang Kuala Simpang Kabupaten Aceh Tamiang sebesar 41,3\%. Diantara variabel bebas yang diteliti kualitas jasa merupakan variabel yang paling dominan.

\section{ACUAN PUSTAKA}

Bambang dan Lina, Metode Penelitian Kuantitatif, Jakarta: PT. Raja Grafindo Persada, 2012.

Bungin, Burhan. Metode Penelitian Kuantitatif: Komunikatif, ekonomi dan kebijakan public serta ilmu lainnya, Jakarta: Kencana, 2009.

Consuelo, G. Sevilla et all. Pengantar Metode Penelitian, Terj. Alimuddin Tuwu, Jakarta: UI Press, 1993.

Djumhana Bastaman, Hanna. Meraih Hidup Bermakna, Jakarta: Paramadina, 1996.

Gilbert, G.R. et.al, Measuring Customer Satisfaction in The Fast Food Industry: A cross-national Approach, The Journal of Services Marketing, 2004.

Kelinger, Asas-asas Penelitian Behavior, Yogyakarta: Gadjah Mada University Press, 1993.

Kotler, Philip. Manajemen Pemasaran Jilid 1 (Penerjemah, Benyamin Molan), Jakarta: PT. Indeks, 2005.

Lestari, Menyimak Kepuasan Pelanggan di Mancanegara, 2009.

Sugiyono, Metode Penelitian Bisnis, Bandung: Alfabeta, 2002.

Suliyanto, Ekonometrika Terapan Teori dan Aplikasi, Yogyakarta: Andi, 2011.

Sufyan Mulazid, Ade. Kedudukan Sistem Pegadaiaan Syariah Dalam Sistem Hukum Nasional Di Indonesia, Jakarta: Departemen Agama, Cet. 1, 2012. 